\title{
Evaluation of Improved Banana (Musa spp.) Varieties in Bale: The Case of Ginnir Districts, South Eastern Ethiopia
}

\author{
Getachew Aseffa*, Mohammed Beriso, Guta Eshetu \\ Oromia Agricultural Research Institute, Sinana Agricultural Research Center, Bale-Robe, Ethiopia
}

Email address:

getachewas@yahoo.com (G. Aseffa)

${ }^{*}$ Corresponding author

\section{To cite this article:}

Getachew Aseffa, Mohammed Beriso, Guta Eshetu. Evaluation of Improved Banana (Musa spp.) Varieties in Bale: The Case of Ginnir Districts, South Eastern Ethiopia. International Journal of Applied Agricultural Sciences. Vol. 6, No. 4, 2020, pp. 72-75.

doi: $10.11648 /$ j.ijaas.20200604.13

Received: March 9, 2020; Accepted: June 12, 2020; Published: June 28, 2020

\begin{abstract}
Adaptation trial of desert type banana varieties was conducted at Ginnir districts of Bale zone south eastern Ethiopia. Seven desert types of improved banana varieties and one local variety were planted at three PA's of Ginnir districts. Analysis of variance revealed that there is significant variation among the varieties. Accordingly, Jiant Cavendish recorded the highest number of finger per bunch (90.33) followed by Dwarf Cavendish (90), the longest and the heaviest finger while the lowest number of finger per bunch recorded from Poyo as well as lower yield comparative with local variety. On the other hand, Dwarf Cavendish and Jiant Cavendish gives higher yield than others and recorded 67.47\%, 22.04\% yield advantages over local varieties, whereas, Jiant Cavendish recorded $64.48 \%, 14.87 \%$ yield advantage over local variety and national average productivity of the crop. Additionally, Grand Nain recorded $60.82 \%, 6.09 \%$ yield advantage over local variety and national average productivity of the crop. Therefore, these three varieties (Dwarf Cavendish, Jiant Cavendish and Grand Nain), well adapted and recorded maximum yield advantage over local and national average productivity of banana and thus recommended for banana producing community at study area.
\end{abstract}

Keywords: Banana, Sucker, Finger, Bunch

\section{Introduction}

Banana (Musa sp.) is one of the most important tropical fruits and evolved in the humid tropical regions of South East Asia with India as one of its centers of origin. Bananas including dessert and cooking types, are giant perennial monocotyledonous herbs of the order Zingiberales, a sister group to the well-studied Poales, which include cereals [1]. It does not originate from Africa it introduced to East African highland regions between the first and sixth century AD [2], [9]. As a result a wide range of unique varieties available that are belonging to the East African highland bananas and the region has been considered as secondary center of Musa diversity [10]. Bananas contribute greatly to the diet in large regions of Africa [11]. The crop represents the world's second largest fruit crop with an annual production of $129,906,098$ metric tons [4]. Banana is the cheapest source of carbohydrate and a good source of vitamins A, B, C and minerals, which other staple food crops such as cassava, potato and cereals are lacking. Banana is one of the important fruit crops used both as staple and dessert [15]. Banana provides a starch staple across some of the poorest parts of the world in Africa and Asia, while dessert bananas are a major cash crop in many countries. The all year round fruiting habit of bananas puts the crop in a superior position in bridging the 'hunger gap' between crop harvests. Banana therefore, contributes significantly to food and income security of people engaged in its production and trade, particularly in developing countries. In Africa they provide more than $25 \%$ of the carbohydrate requirements for over 70 million people [5].

Major banana- producing countries that accounted for about $75 \%$ of total banana production are located in the developing world [12]. No species of Musa is native to Ethiopia and only the neighboring genus Ensete is naturally present. In Ethiopia, it is a most important fruit in terms of both production and consumption). In Ethiopia, suitable conditions are found at Rift Valley, while the cultivation of 
Ensete dominates in highlands of Ethiopia. It is produced throughout the country wherever there is adequate rainfall or irrigation opportunity. It is the second major fruit crop produced next to citrus [14].

Banana, especially the dessert banana is the major fruit crop in Ethiopia leading both in area and production. Dessert banana is the major fruit crop that is most widely grown and consumed in Ethiopia. It is cultivated in several parts of the country where the growing conditions are favorable. especially in the south and southwestern as well as south eastern parts of the country, it is of great socioeconomic importance contributing significantly to the overall wellbeing of the rural communities including food security, income generation and job creation. About 104,421.81 hectares of land is under fruit crops production in Ethiopia. Bananas contributed about $56.79 \%$ of the fruit crop area followed by avocadoes that contributed $17.26 \%$ of the area. More than 7,774,306.92 quintals of fruits were produced in the country. Bananas, Mangoes Avocados, Papayas, and Oranges took up $63.49 \%, 13.50 \%, 10.47 \%, 6.99 \%$ and $3.93 \%$ of the fruit production, respectively [6].

Local cultivars of banana were under cultivation in Ethiopia for long period of times. These local varieties are low yielder and less demand on market. As a result a number of high yielding banana varieties were introduced and adapted in the country. According to MoARD (2006), in Ethiopia there are seven dessert and five cooking type banana varieties released by the research system. Besides, different local varieties that are produced in almost all part of the country by small-scale farmers as garden crop mainly for home consumption and in some cases for sale in local markets.

In Ethiopia about 59,298.19 ha is covered by Banana and $4,936,022.34$ quintals are harvested annually. CSA (2011) also reported as the national yield potential of the crop is 83.24 quintals per hectare. On the other hand, in 2010 Meher cropping season 1,228,662 house holders was participated in banana production and about $13,156.6$ hectares of land was covered with this crop, where 881,327.17 quintals were harvested annually in Oromia Regional state. The average yield potential of banana in Oromia regional state is 66.99 quintals per hectare and is lower than that of the national yield potential of the crop (CSA, 2017/18). However, improved varieties of banana can give higher yield than the mentioned yield potential. Bale zone is known as wheat and Barley belt. However, the Zone has high potential for other crops like pulse and oil crops, horticultural and high hand seed spices. Banana is one of the most important fruit crops grown in Bale low lands viz... Dello Mena, Harena Buluk, Berbere, and some part of Ginnir, Gassera and Agarfa even if local cultivars of banana were under cultivation for long period of times. These local varieties are low yielder and less demand on market and planting material is mostly from local and they get low yield due to lack of high yielding and lack of sufficient quantity of suckers of improved Banana varieties. Hence, this experiment was conducted with the objective of evaluating the adaptability of improved desert type banana varieties to Ginnir districts of Bale zone.

\section{Material and Methods}

\subsection{Experimental Site}

The experiment was conducted in South eastern Ethiopia, Bale Zone, at Ginnir district during 2018 to 2019. Ginnir is located at $40.702 \mathrm{~N}$ and $7.143^{\prime} \mathrm{E}$ at an altitude of 1900 (m.a.s.l). The area possesses a bimodal rainfall type. This bimodal rainfall system has created conducive opportunities to banana production with simple irrigation supplement throughout the year. Average annual maximum and minimum temperatures are 21 and $11^{\circ} \mathrm{C}$, respectively. The dominant soil type is pellic vertisol

\subsection{Experimental Materials and Design}

Seven dessert types of banana varieties namely; Williams1, Grand nain, Robusta, Butazua, Poyo, Jiant Cavendish and Dwarf Cavendish were planted at Ginnir district at three PA's (Chancho, Dodo and Tullicha). Local Variety was used as local check for comparison. The experiment was laid out in randomized complete block design (RCBD) with three replications. Four plants for each variety were planted in each replication with spacing of 2.5 meter between plants and 2.5 meter between rows. All agronomic recommendations for banana production were kept constant for all varieties.

\subsection{Data Collection and Analysis}

Bunch weight was measured using field balance after taking the bunch from the banana plant and number of fingers per bunch was recorded after counting fingers in each bunch. Then after fingers were separated from bunches and fingers were weighted in kilogram and fingers per bunch were counted. All fingers separated from a bunch, weighted and divided to the number of fingers counted in each bunch to obtain finger weight in grams, and fruit yield per hectare was obtained by multiplying number of fruits produced in a hectare by the mean weight of fingers and converted to ton per hectare. Finger length and finger diameter were measured in centimeter using ruler taking randomly selected 10 fingers from each bunch obtained from each plant in each replication

All collected data were inserted to Gen Stat $16^{\text {th }}$ Edition computer software to determine the significant effects of treatments on the parameters. Least Significance difference was used for mean separation at 5\% level of significance.

\section{Result and Discussions}

Analysis of variance showed that number of finger per bunch was significantly different at $5 \%$ level of significance due to variety. Accordingly, the highest number of finger per bunch (90.33) was recorded for Jiant Cavendish followed by Dwarf Cavendish varieties whereas the minimum number of finger per bunch (55.67) was obtained from Poyo variety. On the other hand, the average length of randomly sampled fingers showed that the longest finger $(12.38 \mathrm{~cm})$ was obtained from Jiant Cavendish variety whereas the shortest finger length $(9.89 \mathrm{~cm})$ was recorded from local variety 
which was used as local check. This may be due to potential of improved banana varieties than local.

Average weight of finger of banana was also determined and showed significant variation $(\mathrm{P}<0.05)$ among the varieties. Accordingly, the heaviest finger $(0.3 \mathrm{~kg})$ was obtained from Dwarf Cavendish variety whereas the lowest weight of finger $(0.12 \mathrm{~kg})$ was recorded for Robusta variety. Likewise, average weight of bunch per plant was also determined. The maximum weight of bunch per plant was recorded for Dwarf Cavendish variety followed by Jiant Cavendish and Grand Nain. However, the minimum average weight of bunch per plant was obtained from Poyo variety and Local.

Those varieties with high number of fingers per bunch, long finger, maximum weight of finger and maximum average weight of bunch per plant is preferable by farmers interims of yield performance. Incase Jiant Cavendish, Dwarf Cavendish and Grand Nain variety showed very good performance. Butazua and William-I variety gives relatively good average weight of bunch per plant than Local and Poyo variety. The average yield also showed significant $(\mathrm{p}<0.05)$ difference among the mean of varieties. Accordingly, maximum yield was recorded from Dwarf Cavendish (106.77 $\mathrm{qt} \mathrm{ha}^{-1}$ ) followed by Jiant Cavendish $\left(97.78 \mathrm{qt} \mathrm{ha}^{-1}\right)$ whereas the lowest yield was obtained from Local and Poyo variety. Dwarf Cavendish showed 67.47\%, 22.04\%, Jiant Cavendish $64.48 \%$, 14.87\% Grand Nain 60.82\%, 6.09\% Yield advantage over local variety and national average productivity of the crop (Table 1). This is in line with [8] who indicated the maximum number of hands per bunch was recorded for the improved banana variety Pisang and the minimum number of hands per bunch was recorded for the local check and the maximum number of fingers per hands were recorded for the improved banana varieties Dwarf Cavendish, Giant Cavendish and Poyo and the minimum number of fingers per hand was noted for the local check. However, this is in contrary with [15] who indicated local collections were recorded higher finger yield per hectare than introduced banana varieties. This may be due to environmental conditions of study area which possess low altitude.

Table 1. Mean performance of Yield and yield components of banana varieties evaluated at Ginnir district in 2018 and 2019.

\begin{tabular}{|c|c|c|c|c|c|c|}
\hline S. $\mathbf{N}$ & Varieties & $\begin{array}{l}\text { No of finger per } \\
\text { bunch }\end{array}$ & $\begin{array}{l}\text { Length of finger } \\
(\mathrm{cm})\end{array}$ & $\begin{array}{l}\text { Average Weight of } \\
\text { finger }(\mathrm{kg})\end{array}$ & $\begin{array}{l}\text { Average weight of } \\
\text { bunch per plant }\end{array}$ & $\begin{array}{l}\text { Total Yield } \\
\text { (Qt/ha) }\end{array}$ \\
\hline 1 & Jiant Cavendish & 90.33 & 12.38 & 0.27 & 24.37 & 97.78 \\
\hline 2 & Dwarf Cavendish & 90.00 & 12.04 & 0.30 & 26.69 & 106.77 \\
\hline 3 & Butazua & 84.67 & 10.86 & 0.16 & 13.78 & 55.12 \\
\hline 4 & Grand Nain & 83.00 & 11.83 & 0.27 & 22.16 & 88.64 \\
\hline 5 & Robust & 76.67 & 10.35 & 0.12 & 9.33 & 37.32 \\
\hline 6 & Local & 61.67 & 9.89 & 0.13 & 8.68 & 34.73 \\
\hline \multirow[t]{3}{*}{8} & Poyo & 55.67 & 10.17 & 0.15 & 8.46 & 33.84 \\
\hline & Mean & 75.40 & 10.96 & 0.19 & 15.52 & 62.10 \\
\hline & CV $(\%)$ & 19.40 & 4.80 & 14.1 & 21.60 & 21.60 \\
\hline \multicolumn{2}{|c|}{ Level of significance } & $25.56^{*}$ & $0.93 * *$ & $0.05 * *$ & $5.87 * *$ & $23.48 * *$ \\
\hline
\end{tabular}

*Significant difference, *highly significant difference, $\mathrm{CV}=$ coefficient of variation.

\section{Conclusion and Recommendation}

The study confirmed that there were existences of considerable variations among the tested varieties in terms of yield and yield components viz.. mean number of finger per bunch, average length of fingers, fingers weight, weight of bunch per plant. The highest mean yield performance and yield advantage over local checks indicated us, Dwarf Cavendish, Jiant Cavendish and Grand Nain which were recorded total fruit yield above mean were recommended for farmers producing banana at the study area and similar agro-ecology.

\section{References}

[1] Ange 'liqueD'Hont, 2012. The banana (Musa acuminata) genome and the evolution of monocotyledonous plants. Letter, doi: $10.1038 /$ nature 11241 .

[2] Baker RED, Simmonds NW. 1952. Bananas in East Africa. Pt. II. Annotated list of varieties. Empire Journal of Experimental Agriculture 20: 66-76.

[3] CSA, 2017/18, The Federal democratic republic of Ethiopia,
Central statistical agency, Agricultural Sample Survey, Vol. 1, pp: $10-18$.

[4] FAOSTAT 2010. Food and Agricultural Organization of the United Nations. pp. 28-30.

[5] IITA 1998. Plantain and Banana Improvement ProgramAnnual Report for 1997. International Institute of Tropical Agriculture, One, Nigeria.

[6] MoA (Ministry of Agriculture) 2011. Animal and Plant Health Regulatory Directorate Crop Variety Register Issue No. 14 June, 2011. Addis Ababa.

[7] INIBAP 1992. International network for the improvement of banana and plantain. Annual Report. 1992. Montpellier. France. p. 48.

[8] Tekle Yoseph, Wondewosen Shiferaw, Zemach Sorsa, Tibebu Simon, Abraham Shumbullo, Woineshet Solomon. Adaptability Study of Banana (Musa Paradisiacal var. Sapiertum) Varieties at Jinka, Southern Ethiopia. American Journal of Agriculture and Forestry. Vol. 2, No. 6, 2014, pp. 250-255. doi: 10.11648/j.ajaf.20140206.13.

[9] Price, N. S. (1995). In: Gowen, S. (ed.). The origin and development of banana and plantain cultivation. Chapman and Hall, London, UK. pp. 1-13. 
[10] Swennen, R and Vuylsteke, D. R. (1987). In: Persley, G. J. and De Langhe, E. A. (eds.) Morphological taxonomy of plantain (Musa cultivars AAB) in West Africa. Banana and plantain breeding strategies: Proceedings of an international workshop held at Cairns, Australia, 13-17 Oct. 1986. AClAR Proceeding 21: 165-171.

[11] Swennen, R., Vuylsteke, D. and Ortiz, R. (1995). Phenotypic diversity and patterns of variation in West and Central African plantains. Economic Botany 49: 320-327

[12] Shaibu, A. A., E. A. Maji and M. N. Ogburia. 2012. Yield evaluation of plantain and banana landraces and hybrids in humid agro ecological zone of Nigeria E3 Journal of Agricultural Research and Development Vol. 2 (3). pp. 074079 .
[13] Robinson, J. C., \& Saúco, V. G. 2010. Bananas and plantains, Vol. 19. Cabi. Seifu, G.-M. (1999). Banana: Production and utilization in Ethiopia (pp. 58).

[14] Xavier Perrier, Christophe Jenny, Frédéric Bakry, Deborah Karamura, Mercy Kitavi, Cécile Dubois, Catherine Hervouet, Gérard Philippson and Edmond De Langhe. East African diploid and triploid bananas: a genetic complex transported from South-East Asia. Annals of Botany 123: 19-36, 2019 doi: $10.1093 /$ aob/mcy156.

[15] Wassu Mohammed, Kebede W/Tsadik, Tekalign Tsgaw and Kiflemariam Yehula 2014. Evaluation of Genetic Variation in Local and Introduced Desert Banana (Musa sp.) Genotypes for Morpho-physicochemical Traits. Science, Technology and Arts Research Journal Sci. Technol. Arts Res. J., Oct-Dec 2014, 3 (4): 19-28. 